\title{
Competence Based Education and Training For Social Economic Transformation
}

\author{
Ignatius Isaac Dambudzo \\ Zimbabwe Open University, \\ P0 Box MP1119, Mount Pleasant Harare.
}

\begin{abstract}
Concern has been expressed over the employability and inept demonstration of skills at work by TVET graduates. This has led to questions about the reasons for the negative outcomes. A combination of observations, discussions in comparative studies led to scrutiny of the training of TVET school leavers. The study sought to discover strategies that can be employed to enhance the quality of outcomes and employability of college leavers. This was a qualitative study in which data collection from $\mathbf{3 5}$ trainees was done using observation reports of teacher trainees. Results have shown that employment of CBET may enhance skills development due to the element of industrial attachment where trainees will work under experienced and knowledgeable mentors as trainee teachers do. The model used for teacher training was recommended for other TVET sectors to enable the participation of industry in the training of future personnel within their environment. Trainees expressed satisfaction with the use of CBET because it exposed them to both natural working environment and mentoring by experienced and knowledgeable experts. The training arrangement enhanced their skills and knowledge in preparation for the world of work on completion. CBET was therefore an alternative training method which can be extended to industry from teaching.
\end{abstract}

\section{INTRODUCTION}

There is a general complaint by employers about the lack of preparedness of school and college leavers for industry and commerce. Consequently large numbers of college leavers equipped with technical, vocational, education and training skills remain unemployed. The youth are said to lack entry level skills. This has been attributed to a mismatch between what employers want and what skills the youth are offering on the job market. Others have gone on to say that educators and industry were operating in two different worlds. The two do not understand each other and appear to lack an understanding or respect for interests and requirements for the other and yet TVET institutions are there to service industry and also ensure that their graduates get employed for personal and industry's benefit in order to promote socioeconomic transformation. (Davis, 2004). Young people get frustrated if they cannot get employed. Families remain poverty stricken. Government continues to receive low income returns as demand for industrial goods remains low or even decline because people have low buying power due to high unemployment. Poverty persists, general economic decline is experienced and government revenue fails to meet the country's demands. The question therefore is: What can be done to match skills produced by TVET institutions and what industry demands? Alternatively: What can TVET institutions do to enhance youth employability? (Law, 2007, Kilter, 2000, Davis, 2004). One of two strategies can be adopted. First, institutions can incorporate employability or generic skills in their training programmes. Second, institutions can employ Competence Based Education and Training (CBET) as an appropriate pedagogy. (Foyster, 1990, COTVET, 2009, Belawatti \& Wardani, 2005) This paper will focus on CBET to show how it can enhance youth employability as well as promote socioeconomic transformation in Zimbabwe. 
CBET is a form of pedagogy which is holistic, practical, and integrative and makes for quality delivery. It is aimed at skills development with a clearly defined mode of delivery, prepares individuals for both self-employment and full employment in industry. It is outcomes based, developed and implemented with employer participation and is delivered in the TVET institution and workplace as well. (Anane, 2013, Kilter, 2000, Law, 2007). An appreciation of the environment in which we live and work will highlight the importance of CBET in TVET.

\section{BACKGROUND}

1. It is generally recognised and accepted that TVET is key to socio-economic transformation in any country hence very important.

2. Our environment is experiencing rapid change due to globalisation and technological changes and CBET is a flexible mode of TVET delivery.

3. Current concerns include ensuring relevance, responsiveness and value of TVET to the global economy.

4. Proper development of TVET is vital for the economic development of every country due to the knowledge driven and competitive global economy.

5. TVET enables individuals and societies to unlock their potential, expand their horizons and adapt to changes in a dynamic world thereby making education more responsive to changing goals and aspirations. CBET can make this possible.

6. It is generally recognised that policies on human resources development (HRD), poverty reduction, employment creation and accelerated economic growth can be achieved through TVET hence everything possible should be done to ensure its success in producing the right calibre of workers. (Law, 2007)

It is the above environmental factors and conditions which lead to the call for a new approach to the provision of TVET and CBET can answer to some of these challenges. What is CBET?

CBET is an industry and demand or outcomes based education and training founded on welldefined or structured industry generated standards also called 'occupational standards'. This means that the curriculum, assessment and learning materials design and development are all based on industry standards. Its main focus is on the development of knowledge, skills, attitudes and values that enable one to be successful in the workplace. Emphasis is on what one can do in the workplace rather than mere theoretical knowledge. In other words, CBET is an integration of the delivery of technical knowledge, knowledge and generic or employability skills. (Law, 2007; Anane, 2013). In short this is what CBET offers:

\section{CBET > > > > Technical skills +Knowledge + generic +employability skills}

Anyone leaving a TVET college with such knowledge and skills can be said to be INDUSTRY COMPLIANT or READY. In order to understand its application it is important that the structure of CBET be given. (See Figure 1). 


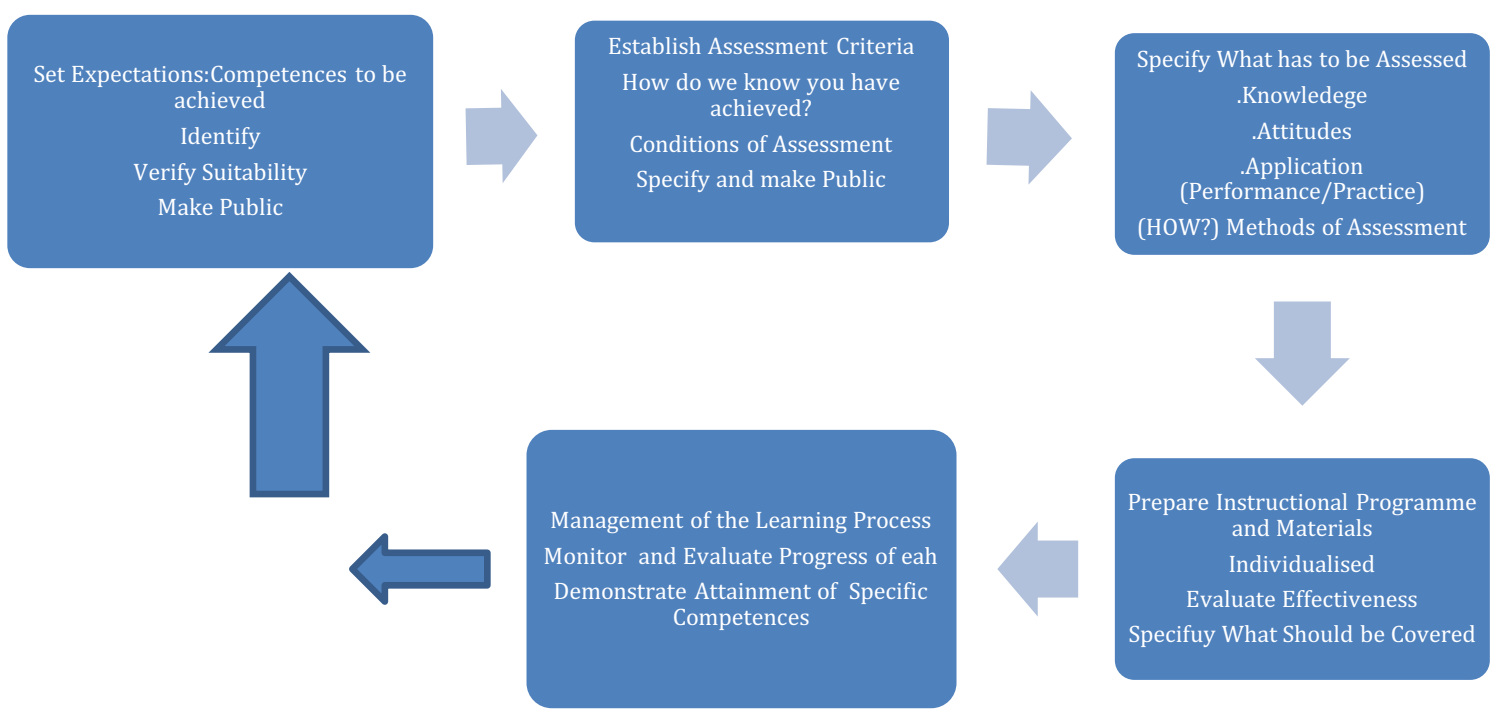

Figure 1: Structure of CBET (Source: Dambudzo, 2016)

Figure 1 summarises the structure and content of CBET. It demonstrates that CBET is a pedagogic model: It involves, teaching or instruction, designing and development of learning materials guided by the expectations or objectives to be achieved in terms of competences. It is this holistic structure and content which makes it a rich methodology for TVET. It is its focus on the workplace and outcomes which is key in TVET and employability. Apart from structure, the figure also shows the characteristics of CBET. These according to COTVET (2009), Davis (2004) and Law (2007) include:

1) Careful selection of competences to be developed in an individual

2) Integration of theory and practice

3) Preparation of appropriate materials to support the acquisition of knowledge and skills

4) Methods of instruction to be used to achieve mastery of knowledge and skills required in a given time

5) Assessment of knowledge and skills at entry point and as one progresses through the course or programme

6) Differentiated learning (Allows individuals to progress at their own pace)

7) Allows for flexible training approaches such as large or small groups, individual study and project work

8) Utilisation of support materials such as print, audio-visual, simulations or models relevant to the skills and knowledge to be developed

9) CBET is learner-centred

10)CBET specifies when one has completed the programme and achieved specified skills and knowledge after assessment. (Delker, 1990, Foyster, 1990 \& Norton, 1987). The above show the extent to which CBET as a training strategy is more purposeful than other approaches. It keeps the trainee focused on the application of knowledge and skills in the work place. Supervisors know what the trainee should do on a daily basis, the trainee with the guidance of the supervisor plans daily activities so that there is no idle time or unfocused activities. By remaining so focused, the trainee can tell where he/she still has deficiencies and can get assistance from the mentor and other supervisors in the workplace.

Objectives of CBET have already been specified. An important point is that CBET works to achieve measurable standards as part of developing competent individuals with 
transferable skills relevant to the needs of industry. It develops potential of individuals thereby give confidence to future employers and employees. CBET trained individuals fit into the job market very easily as teachers do. This promotes youth employment, reduces poverty and creates wealth for the nation through socio-economic transformation.

\section{How is CBET Delivered?}

It should be remembered that the way any curriculum is delivered will also determine ability to apply it in the world of work. It will also affect the way the material will be learnt and assimilated. The same applies to the way modules are designed and developed. They should be able to support skills and knowledge acquisition. For example, ODL modules used to train teachers by Zimbabwe Open University (ZOU) have content, presentation and self-assessment activities which encourage skills and knowledge acquisition for participants to function as teachers in the classroom later. In other words, they are tailor-made for pedagogical purposes. (Norton, 1987). Thus the module is the teacher for knowledge and skills development and application in the field (classroom). Generally, methods of teaching have shifted from the traditional mode where the teacher dominated information delivery to the more modern learner-centred and constructivist approach where students are largely responsible for knowledge creation and meaning construction. It is important to note that from time to time the educator may use both the teacher and learner-centred approaches depending on the situation but the learner-centred is the more dominant in CBET.

- Facilitation or delivery methods often used are summarised in Figure 2. Using CBET provides scope for maximum involvement of students in knowledge and skills acquisition and application. Trainees interact, share views and alternatives in problem solving. When in the laboratory, workshop or fieldwork, they investigate problems and find answers (Action Research) to them and there is more learning involved through maximum and individual participation. Work experience is another form of learning or delivery of content in CBET. Some call it internship others attachment or work related learning (WEL). Whatever name it is called by, WEL is used in conjunction with CBET for the following objectives: To enable CBET learners to develop:

- Planning skills,

- Organisational skills,

- Problem-solving skills,

- Self-awareness and

- Technical competence in real work situations with support from experienced and knowledgeable facilitators in a relevant industry for their training. Students will be placed in a relevant workplace under an appropriately qualified and experienced supervisor (mentor). Industrial attachment is both a learning and assessment method in CBET. In CBET, training institutions identify appropriate industries with appropriate standards to place the students for training purposes. Students are closely monitored on a daily basis, weekly or monthly. Logbooks are completed to show what the student has covered and at what level of competence. Facilitators, assessors and verifiers are all concerned about ensuring the acquisition of the standards set. Credits are awarded which count towards final grade and certification. This is unlike the traditional approach to attachment where the student finds own industry for placement, monitoring is erratic, no well-trained assessors prepared to provide supervision. The attachment in the traditional approach is not credited towards certification because there are no standards to be met. Workplace experience has benefits for the student, TVET institution and industry as outlined below.

- Quality of training and relevance of knowledge and skills are enhanced 
- Students gain competence by applying knowledge and skills while they learn

- Students gain in confidence in work situations

- Training time is used effectively and efficiently

- More mentors' and supervisors' time is spent with trainees

- More time (trainees, mentors \& supervisors) is spent on evaluation

- The approach ensures sustainable development of industries and the nation as a whole.

The success however, would depend on how thoroughly the facilitator plans the learning experience guided by the occupational standards/professional standards to be acquired and achieved. This starts off with what the module seeks to achieve to the minute detail of the learning unit being studied. For example, in a module unit on making joints in wood technology the following can be part of the plan:

Aim/Expectation: On completion of the module the learner should be able to demonstrate basic knowledge of different types of joints, tools for making joints and their operations. This is a broad goal which needs to be broken down into smaller and more manageable tasks to develop the skills and knowledge of joint making. To do so we need to specify learning outcomes as performance criteria.

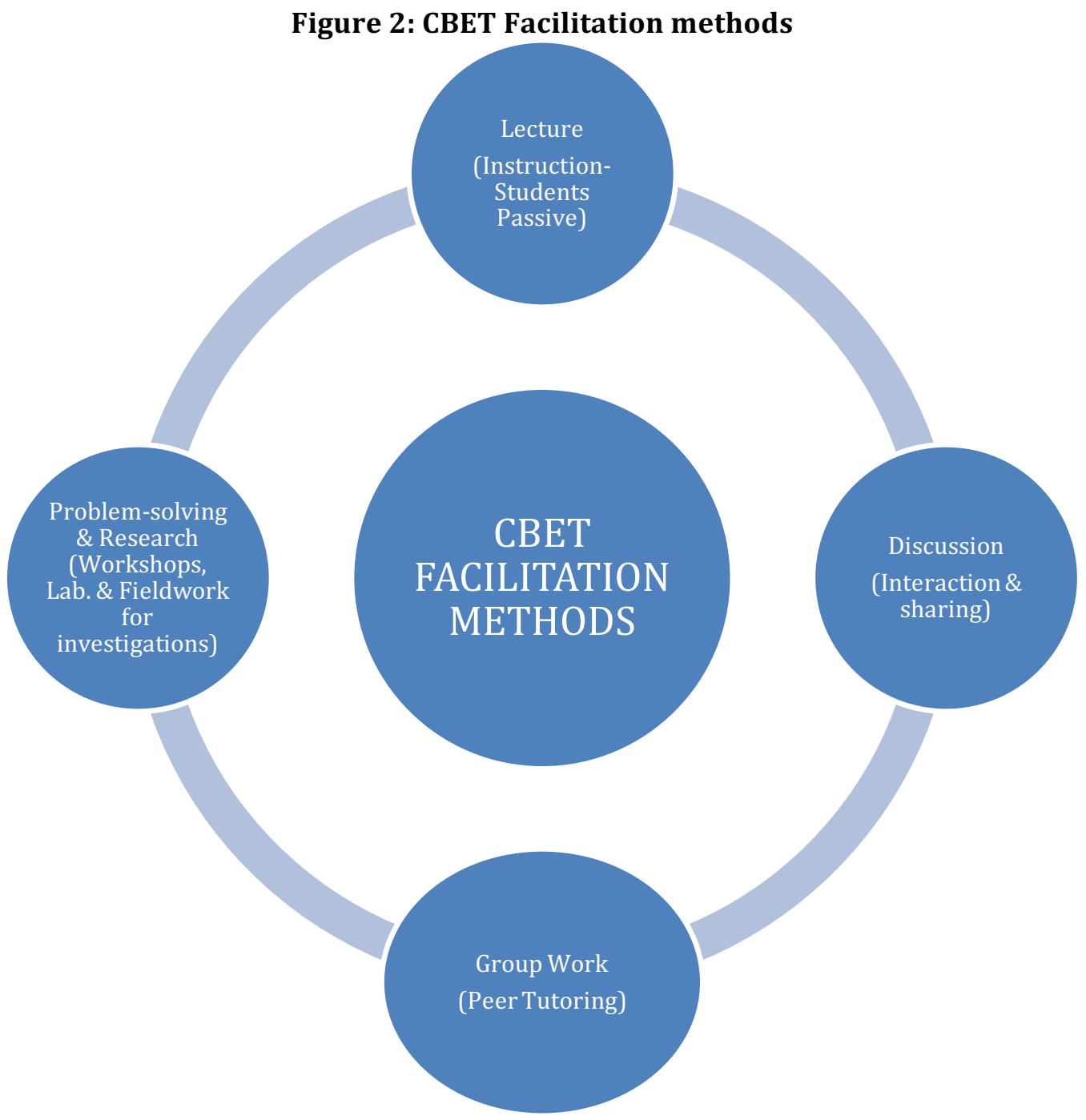

Examples of learning Outcomes: The following can be examples of learning outcomes which facilitators can set for trainees. By the end of the unit trainees should be able to:

1. identify appropriate tools for wood technology

2. use each of the tools appropriately 
3. Demonstrate knowledge of the tools and their uses

4. Demonstrate knowledge of the processes of making different types of joints

5. Explain principles of joint making

6. Explain working principles of tools used

7. Demonstrate knowledge of different types of timber and its application

Evidence of performance against the standards set can only be obtained through assessment of individual students hence the importance of well-developed assessment tools in addition to good lesson planning. It should be noted that from the above outcomes the learning unit has been broken down into small measurable outcomes. For example,

(a) Learning outcomes which seek knowledge and skills learnt.

(b) Performance criteria which seek knowledge and skills attained to achieve the performance outcomes.

(c) Content coverage or statements to support the performance

(d) Evidence required or assessment criteria to be used to determine attainment of desired competences

Used as described above, CBET becomes a data collection tool for evidence of one's performance to enable evaluation or judgement of how far one has met the performance standards set for the module in terms of knowledge and skills acquired. This leads to an examination of the assessment methods that TVET institutions embracing CBET can use.

\section{Assessment Methods in CBET}

Three methods of assessment have been used successfully and effectively by those using CBET in TVET.

I. Observation of the learner in action or performing a task related to the module completed. In teacher education this involves lesson observation where the facilitator observes a student applying teaching techniques and principles learned in a given subject. It can also involve observing a student making a joint-how wood is cut, planed, glued etc. The facilitator will be able to tell whether the student has mastered the skill or not.

II. Product. Assessors will look at the artefact made by the student to see whether it meets the standards set. Different characteristics of the end product will be looked at to see whether they fit the purpose for which it has been made. For a trainee teacher, this may involve looking at the lesson plan, learners' exercise books to see if they have been marked following the set standards, file and its organisation, teachers' dress or deportment, chalkboard work, classroom and class management etc. If each meets the set standards then one passes.

III. Written responses to questions. Students can be asked questions for written or oral answers. The questions will be seeking knowledge and skills in a given area to establish whether one knows what one is doing.

\section{LESSONS WE LEARN FROM TRAINING OF TEACHERS USING CBET}

Teacher training is another TVET field which appears to have used CBET for a while. An example of teacher development through Open and Distance learning (ODL) will be cited. How does the model assimilate the CBET? As already detailed above, CBET is a holistic approach to training and development. It incorporates pedagogy, assessment, evaluation and certification. How does teacher development through ODL conduct the training?

1. Individuals who meet basic entry qualifications such as five ' $O$ ' level subjects including English language, Mathematics and Science can register to train as teachers. 
2. Upon registration the student is given Modules which cover principles of education, professional studies, and subject content and teaching techniques. Among the modules is one on Teaching Practice to guide the student during preparation and the actual teaching practice in the school and classroom.

3. Tutorials are held throughout the training programme to empower the students with knowledge and skills for teaching.

4. Practical sessions are held to sharpen key skills for teaching and learning. For example, questioning techniques, lesson planning, introducing a lesson, use of media to deliver a lesson, use of role play, group work, whole class, textbook, and the local environment as teaching strategies.

5. Students are taught how to give written and other assignments and how to mark them or give feedback.

6. Students are then given an opportunity to practise on a small scale in what is commonly known as 'micro-teaching' (Teaching part of a lesson to a small group of say, five learners while peer students and a tutor observe).

7. After the micro-teaching session the student is asked to make comments about his/her own experiences of the lesson and then the peers make comments on their observations and finally the tutor. The feedback is very useful. Weaknesses and strengths are highlighted and areas for further improvement are specified.

8. The student is then prepared for the teaching practice which lasts anything from a semester (six months) to a year and half depending on the programme one is on.

9. Before going out on teaching practice the students have preparatory workshops during which all the expectations on TP are specified. This covers, lesson preparation, planning, classroom management, marking of books, dress, team work working relationships with head, mentor, head of department and other teachers and what to do when they meet challenges.

10. Students are then deployed if they are not in a school already. They will be armed with the teaching practice guide and module for reference.

11. In the school, students are expected to be supervised and reported on by the head, mentor or anybody delegated by the head as continuous assessment to sharpen their skills. Thus, the students in the majority of cases are placed in the hands of experts in the teaching field who can share their experience with the novices. This is like on the job training (OJT).

12. University lecturers will follow up to supervise the students to complement the work of school based supervisors. Assessment grades are given to reflect the level of competence the students have reached. A written report which includes both numerical score as a percentage and narrative are given to inform the student as much as possible about their performance. The TP file is also examined to get an idea of what has been going on or what the student does during the period when the university tutors are not there.

13. Consistent with CBET methods student assessment involves: (1) Observation of the student teacher teaching a lesson (process) to see how far teaching principles have been grasped and are being implemented, (2) the TP file (product: contents and organisation), (3) Dress, exercise books, (4) Classroom/class management, (5) lesson plans and schemes of work, (6) media used for teaching and learning-how appropriate and usefulness to support the activities.

14. Throughout the training period written exams are given to test the knowledge and understanding of what has been learnt in preparation to become qualified teachers. It is quite possible that one can pass the practical and fail the written examination. That person cannot be certificated because failure may mean inadequate knowledge and understanding. The opposite is also true-passing written exam and fail Teaching 
Practice. This is a feature of CBET. A look at the assessment form used during teaching practice will highlight the skills that the trainees are expected to master and demonstrate before qualifying as teachers. Basically the form assesses knowledge, skills both technical and generic or employability skills.

\section{APPENDIX A \\ NAME OF INSTITUTION \\ DEPARTMENT OF TEACHER DEVELOPMENT \\ TEACHING PRACTICE SUPERVISION ASSESSMENT FORM}

Name in Full

Programme.

PIN

Intake

Class/Form

Date....

Time

School

Subject...

Topic

\begin{tabular}{|c|c|c|c|}
\hline $\begin{array}{l}\text { Supervision/Assessment } \\
\text { Aspect }\end{array}$ & $\begin{array}{l}\text { Possible } \\
\text { marks } \\
(\%)\end{array}$ & $\begin{array}{l}\text { Mark } \\
\text { Attained }\end{array}$ & $\begin{array}{l}\text { Supervisor's Comments } \\
\text { from observations }\end{array}$ \\
\hline $\begin{array}{l}\text { Schemes of Work } \\
\text { Adequacy and up-to-date } \\
\text { Quality of Preparation } \\
\text { Format of Schemes } \\
\text { Content Breakdown } \\
\text { Evaluation Comments }\end{array}$ & $\begin{array}{c}10 \\
2 \\
2 \\
2 \\
2 \\
2\end{array}$ & & \\
\hline $\begin{array}{l}\text { Lesson Planning } \\
\text { Lesson Aim } \\
\text { Lesson Objectives: Clear and } \\
\text { SMART } \\
\text { Format of Detailed Lesson Plan } \\
\text { Content Sequencing } \\
\text { Teacher/Pupil Activities } \\
\text { Reflective Evaluations }\end{array}$ & $\begin{array}{c}\mathbf{1 0} \\
1 \\
5 \\
1 \\
1 \\
1 \\
1\end{array}$ & & \\
\hline $\begin{array}{l}\text { Lesson Delivery } \\
\text { Lesson Introduction: Relevant, } \\
\text { brief and motivating } \\
\text { Voice projection } \\
\text { Concept and skills } \\
\text { development } \\
\text { Pacing of lesson activities } \\
\text { Organisation of learning } \\
\text { activities } \\
\text { Subject mastery } \\
\text { Teaching strategies, relevance } \\
\text { and variety } \\
\text { Media availability and their } \\
\text { effective use } \\
\text { Teacher-Pupil and Pupil-Pupil } \\
\text { Interaction } \\
\text { Pupil participation and } \\
\text { learning } \\
\text { Questioning techniques }\end{array}$ & $\begin{array}{l}40 \\
3 \\
2 \\
5 \\
2 \\
2 \\
5 \\
5 \\
5 \\
3 \\
3 \\
5 \\
3 \\
2 \\
\end{array}$ & & \\
\hline
\end{tabular}




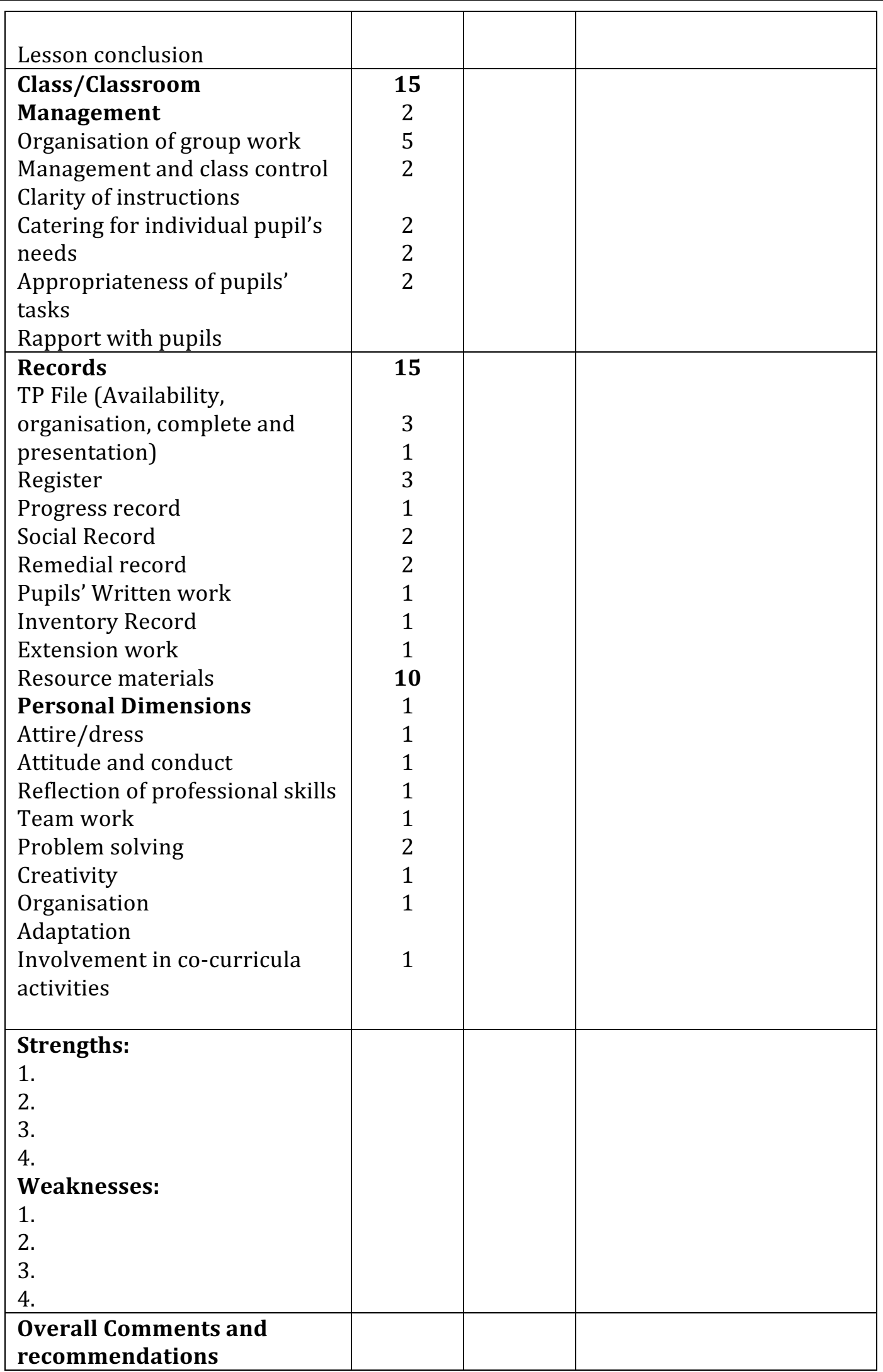

Name of Supervisor

Signature

Designation of Supervisor

Date.

Name of Student

Signature

Date 


\section{APPENDIX B}

Table 1: Supervision/Assessment Form For Trainee Teachers

\begin{tabular}{|c|c|c|c|c|}
\hline SKILLS & KNOWLEDGE & PRODUCTS & PROCESSES & $\begin{array}{l}\text { GENERIC/EMPLOYABILITY } \\
\text { SKILLS (Personal dimensions) }\end{array}$ \\
\hline Scheming & $\begin{array}{l}\text { Scheming } \\
\text { format, what to } \\
\text { put in a scheme } \\
\text { of work, } \\
\text { evaluation of a } \\
\text { scheme of work. }\end{array}$ & $\begin{array}{l}\text { TP File, } \\
\text { Scheme of } \\
\text { work for } \\
\text { every } \\
\text { subject } \\
\text { taught }\end{array}$ & $\begin{array}{l}\text { Read content } \\
\text { of a subject, } \\
\text { decide on } \\
\text { presentation } \\
\text { format, } \\
\text { teaching } \\
\text { strategies, } \\
\text { duration for } \\
\text { each content } \\
\text { area, ability } \\
\text { composition } \\
\text { of the class, } \\
\text { availability } \\
\text { of resources } \\
\text { for teaching } \\
\text { and learning, } \\
\text { Lesson } \\
\text { delivery }\end{array}$ & $\begin{array}{l}\text { Teamwork, problem solving, } \\
\text { creativity, adaptation, involvement } \\
\text { in activities in the school, rapport } \\
\text { with learners and peers, } \\
\text { organisation, co-ordination, } \\
\text { tidiness }\end{array}$ \\
\hline $\begin{array}{l}\text { Lesson } \\
\text { preparation }\end{array}$ & $\begin{array}{l}\text { Subject content; } \\
\text { relevance; } \\
\text { knowledge of } \\
\text { pupils }\end{array}$ & $\begin{array}{l}\text { Teaching } \\
\text { and learning } \\
\text { resources }\end{array}$ & $\begin{array}{l}\text { Looking for } \\
\text { appropriate } \\
\text { resources for } \\
\text { the lesson, } \\
\text { textbooks, } \\
\text { internet } \\
\text { sources, } \\
\text { media and } \\
\text { scanning } \\
\text { school } \\
\text { environment } \\
\text { for } \\
\text { appropriate } \\
\text { illustrations } \\
\text { for the } \\
\text { lesson. }\end{array}$ & $\begin{array}{l}\text { Organisation and creativity, } \\
\text { knowledge of subject matter }\end{array}$ \\
\hline $\begin{array}{l}\text { Lesson } \\
\text { Planning }\end{array}$ & $\begin{array}{l}\text { Planning format } \\
\text { and contents, } \\
\text { stating } \\
\text { objectives } \\
\text { (SMART) } \\
\end{array}$ & Lesson plan & $\begin{array}{l}\text { Write out a } \\
\text { lesson plan }\end{array}$ & $\begin{array}{l}\text { Creativity, organisation, } \\
\text { professionalism, knowledgeable } \\
\text { and skilful in subject area }\end{array}$ \\
\hline $\begin{array}{l}\text { Lesson } \\
\text { Delivery: } \\
\text { Introduction, } \\
\text { use of media, } \\
\text { sequencing, } \\
\text { questioning } \\
\text { technique, } \\
\text { voice } \\
\text { projection, } \\
\text { organisation of } \\
\text { activities, } \\
\text { Concluding a }\end{array}$ & $\begin{array}{l}\text { Different ways of } \\
\text { introducing a } \\
\text { lesson, different } \\
\text { types of media } \\
\text { and their uses, } \\
\text { reflective } \\
\text { evaluation, } \\
\text { effective use of } \\
\text { media }\end{array}$ & $\begin{array}{l}\text { Plot for } \\
\text { agriculture, } \\
\text { woodwork } \\
\text { tools and } \\
\text { items made, } \\
\text { metal work } \\
\text { items made, } \\
\text { processed } \\
\text { documents } \\
\text { using ICT, } \\
\text { baked items, } \\
\text { food, fabric }\end{array}$ & $\begin{array}{l}\text { Use of ICT } \\
\text { for Lesson } \\
\text { delivery, } \\
\text { strategies } \\
\text { used: to } \\
\text { introduce, } \\
\text { pace the } \\
\text { lesson, } \\
\text { interact with } \\
\text { learners, } \\
\text { pose } \\
\text { questions, }\end{array}$ & $\begin{array}{l}\text { Passion, rapport with pupils, } \\
\text { communication skills, } \\
\text { organisation, adaptability, } \\
\text { creativity, competence and } \\
\text { confidence }\end{array}$ \\
\hline
\end{tabular}




\begin{tabular}{|l|l|l|l|l|}
\hline $\begin{array}{l}\text { lesson, lesson } \\
\text { evaluation }\end{array}$ & items & $\begin{array}{l}\text { conclude and } \\
\text { evaluate } \\
\text { lessons }\end{array}$ & \\
\hline $\begin{array}{l}\text { Class/classroo } \\
\text { management }\end{array}$ & $\begin{array}{l}\text { Individual } \\
\text { pupils' } \\
\text { characteristics, } \\
\text { resource } \\
\text { availability, } \\
\text { constraints of } \\
\text { the classroom } \\
\text { environment and } \\
\text { school as a } \\
\text { whole }\end{array}$ & $\begin{array}{l}\text { Sitting plan, } \\
\text { chalkboard } \\
\text { and layout }\end{array}$ & $\begin{array}{l}\text { Management } \\
\text { of learners of } \\
\text { different } \\
\text { abilities, } \\
\text { arrangement } \\
\text { of desks and } \\
\text { chairs, } \\
\text { chalkboard } \\
\text { layout }\end{array}$ & $\begin{array}{l}\text { Teacher-pupil relationships, } \\
\text { pupils interaction }\end{array}$ \\
\hline $\begin{array}{l}\text { Record } \\
\text { keeping }\end{array}$ & $\begin{array}{l}\text { and their value } \\
\text { in teaching and } \\
\text { learning }\end{array}$ & $\begin{array}{l}\text { Class } \\
\text { records: } \\
\text { progress, } \\
\text { register, } \\
\text { social } \\
\text { records etc. }\end{array}$ & $\begin{array}{l}\text { Maintenance } \\
\text { of records on } \\
\text { a daily basis } \\
\text { Use of } \\
\text { records to } \\
\text { improve } \\
\text { teaching and } \\
\text { learning. }\end{array}$ & $\begin{array}{l}\text { Recording skills, organisation, and } \\
\text { communication, co-ordination } \\
\text { with colleagues, head and parents. }\end{array}$ \\
\hline & & & & \\
\hline
\end{tabular}

\begin{tabular}{|l|l|}
\multicolumn{2}{|c|}{ SUMMARY } \\
\hline STRENGTHS & WEAKNESSES \\
\hline 1. & 1. \\
\hline 2. & 2. \\
\hline 3. & 3. \\
\hline 4. & 4. \\
\hline Suggestions for improvement:1. & \\
\hline 2. & \\
\hline 3. & \\
\hline 4. &
\end{tabular}

Source: Zimbabwe Open University, 2016

Table 1 shows the skills which a trainee teacher is expected to master and demonstrate competence (theoretically and practically) in before certification as a qualified teachers. As can be seen the training develops skills, provides and develops knowledge, understanding, making of products, managing processes (the way things are done e.g. lesson scheming, planning and delivery, products made and the generic skills and employability skills which should be demonstrated. Supervisors are expected to make comments on each one of them. If satisfactory then one is likely to pass. The test score as a percentage and qualitative comments should show the level of competence of the individual before certification. Thus, the richness of the training programme using CBET produces a cadre who is flexible and can work in any environment where his /her skills fit. Such is the strength of CBET. Literature has shown that TVET graduates find themselves unemployable because they do not have employability or generic skills. TVET for teachers accommodates all the requirements hence employability is possible beyond the borders of our country where they have received training. This fits in very well with the goals of globalisation in human resource development. How does CBET promote socio-economic transformation and sustainable development?

\section{CBET AND SOCIO-ECONOMIC TRANSFORMATION}

- Prepares a cadre with knowledge and skills in a given field of the economy. 
- Can apply knowledge in the field to enhance productivity

- Enhances employability thereby improves incomes and quality of life for self and family

- Enhances skills for employment creation and increase earnings for self and the country through tax and demand for manufactured goods

- Increases demand for luxury goods thereby increase employment in other areas of the economy

- Poverty alleviation throughout the country

- Enhances quality of life in the country generally

- Expansion of access to education increases demand for building materials and teaching and learning materials.

It is not just enough to train teachers but to pay attention to methods used so that the final product is well equipped with knowledge and skills to apply in real life to solve practical problems in our environment. Further research on other sectors is needed to enhance our appreciation and understanding of the importance of CBET as a training strategy beneficial to our economy.

\section{References}

Anane, C. A. (2013). Competency Based Training: Quality delivery for technical and vocational education and training (TVET)Institutions, Educational research International www.savap.org.pk, Vol 2(2), 117.

Law, S. S. (2007). Vocational Technical Education and Economic development - The Singapore Experience. ITE Paper No.9, 2007, pp. 5.

Norton, R. E. (1987). Competency-Based Education and Training: A Humanistic and Realistic Approach to Technical and Vocational Instruction. Paper presented at the Regional Workshop on Technical/Vocational Teacher Training in Chiba City, Japan. ERIC: ED 279910.

Delker, P. V. (1990). Basic Skills Education in Business and Industry: Factors for Success or Failure. Contractor Report, Office of Technology Assessment, United States Congress.

Foyster, J. (1990). Getting to Grips with Competency-Based Training and Assessment. TAFE National Centre for Research and Development: Leabrook, Australia. ERIC: ED 317849.

COTVET (2009). Report of the Technical Committee on the Harmonisation of Competency-Based Training (CBT) in Ghana. Ghana: COTVET.

Watson, A. (1990). Competency-Based Vocational Education and Self-Paced Learning. Monograph Series, Technology University: Sydney, Australia. ERIC: ED 324443

Killer, R. (2000). Outcomes-based education: Principles and possibilities. http://drjj.uitm.edu.my/DRJJ/CONFERENCE/UPSI/OBEKillen.pdf

Teachernet (2009). Benchmarking: main Text; Department for Children, schools and families, London.

Minimum Teaching Standards' (Ministry of Education, Sports, Arts and Culture, 2013, ZIMCHE Framework, 2010).

Davis, P. (2004), Technical Colleges \& Industry partnerships: Advancing workplace learning and organizational Effectiveness: Industrial and Commercial Training Vol. 36 (3) 121 - 124.

http://dx.doi.org/10.1108/00197850410699137Bbbbbbb

Belawatti, T. \&Wardani, I.G.A.K., (2005). Quality assurance in Distance Education: The experience in Universitas in Terbuka, Indonesia in perspectives of education, Canada. Africa Virtual University (2014). AVU Policy Brief:

Towards a more student-centred mode of teacher training in ODL, Number 2014-08.

Initial teacher Education in Scotland (2000). Quality Assurance in Teacher Education: Benchmark Information...,Consultant Document. 